IZA DP No. 5368

Workers' Views of the Impact of Trade on Jobs

Clair Brown

Julia Lane

Timothy Sturgeon

December 2010 


\title{
Workers' Views of the Impact of Trade on Jobs
}

\author{
Clair Brown \\ University of California, Berkeley \\ Julia Lane \\ National Science Foundation \\ and IZA
}

Timothy Sturgeon

Massachusetts Institute of Technology

\author{
Discussion Paper No. 5368 \\ December 2010
}

\author{
IZA \\ P.O. Box 7240 \\ 53072 Bonn \\ Germany \\ Phone: +49-228-3894-0 \\ Fax: +49-228-3894-180 \\ E-mail: iza@iza.org
}

\begin{abstract}
Any opinions expressed here are those of the author(s) and not those of IZA. Research published in this series may include views on policy, but the institute itself takes no institutional policy positions.

The Institute for the Study of Labor (IZA) in Bonn is a local and virtual international research center and a place of communication between science, politics and business. IZA is an independent nonprofit organization supported by Deutsche Post Foundation. The center is associated with the University of Bonn and offers a stimulating research environment through its international network, workshops and conferences, data service, project support, research visits and doctoral program. IZA engages in (i) original and internationally competitive research in all fields of labor economics, (ii) development of policy concepts, and (iii) dissemination of research results and concepts to the interested public.
\end{abstract}

IZA Discussion Papers often represent preliminary work and are circulated to encourage discussion. Citation of such a paper should account for its provisional character. A revised version may be available directly from the author. 
IZA Discussion Paper No. 5368

December 2010

\section{ABSTRACT}

\section{Workers' Views of the Impact of Trade on Jobs ${ }^{\star}$}

Although public policy is influenced by the perception that workers worry about the impact of trade on their jobs, there is little empirical evidence on what shapes such views. This paper uses new data to examine how workers' perceptions of the impact of trade are related to their career paths, job characteristics, and local labor market conditions. Surprisingly, given prior literature, we find that workers' perceptions primarily reflect local labor market conditions and education rather than labor market experiences or job characteristics.

JEL Classification: J21, J08

Keywords: globalization, trade, job characteristics, local labor markets, job loss, job security

Corresponding author:

Julia Lane

National Science Foundation

4201 Wilson Boulevard

Arlington, Virginia 22230

USA

E-mail: jlane@nsf.gov

\footnotetext{
* This research was made possible by support from the Sloan Foundation and the Institute for Research on Labor and Employment at the University of California at Berkeley. We are grateful for the research support provided by Sean Tanner, Sarah Anders, and Hwa Ryung Lee. Lori Kletzer generously provided her $\mathrm{M}$ index data, and Tim Mulcahy and Chet Bowie of the National Opinion Research Center at the University of Chicago provided access to confidential GSS data in the NORC data enclave. We also acknowledge the invaluable efforts of Norman Bradburn and Alma Kuby in developing high quality survey questions. Key input was also received from Eileen Appelbaum, Arne Kalleberg, Rosemary Batt, Frank Levy, Susan Helper, Melissa Appleyard, Lori Kletzer, Peter Gourevitch, Rafiq Dossani, and John Paul Macduffie.
} 


\section{INTRODUCTION}

Even before the 2008-2009 recession, Americans were worried about their jobs (Anderson and Gascon 2007;O'Rourke 2003;Scheve and Slaughter 2001). While the possible causes of these perceptions of vulnerability are complex, the role of globalization has been the most controversial. The most pressing concern, among researchers, policymakers, and the media, has centered on the possibility of large scale, permanent shifts of jobs offshore, and on the downward pressure this might place on employment and wages in the United States. Recent economic volatility has increased these concerns and driven a new round of protectionist policy responses; worldwide, forty-six new trade restrictions were put in place in the five months following the collapse of Lehman Brothers (Eichengreen 2010).

While there has historically been little evidence that globalization has caused either aggregate job loss or wage decline, even in the manufacturing sector, academics have nevertheless taken the potential link seriously. Some respected economists have questioned whether the benefits of free trade were being oversold (Gomory and Baumol 2001; Rodrik 1997). More current work has generated very large estimates of potential job loss from services offshoring (Bardhan and Kroll 2003;Blinder and Krueger 2009;Kletzer 2009). Other work that measures job loss has confirmed that off-shoring for the purposes of cost cutting is associated with job losses at home (Ebenstein, Harrison, McMillan and Phillips 2009).

If the purpose of trade policy is to respond appropriately to globalization and to the public's fears about trade, policymakers need to understand what shapes workers' perceptions of the impact of trade, as well as the actual impact of trade on jobs. We need to know the link between the results of trade policy and workers' perceptions of trade. Are workers' perceptions based on occupational characteristics that shape the potential for their jobs to be done abroad, or 
on their level of education and prior experiences in the labor market, by what they see happening in the local labor market, or by something else? Unfortunately, there is little direct empirical analysis of the factors that influence workers' views of trade.

This paper begins to fill this gap by drawing on new data from 2008 that allows us to examine how workers' perceptions of the impact of trade on jobs are related to their career paths, job characteristics, and local labor market conditions. A major contribution of this study is the use of more precise proxies of key variables than those used in previous studies. We develop direct measures of workers' perceptions of the impact of trade on jobs, which we use in addition to the standard measures of job insecurity. We also directly measure specific job characteristics, rather than rely only on general descriptions of occupational characteristics, and collect detailed information about career paths, such as earning histories, rather than only current earnings and education. For the workers' local labor market conditions, we use direct measures of local hiring and separation rates in addition to local unemployment rates.

We find that workers' views of the impact of trade on jobs mainly reflect their local labor market conditions and their education. Simply put, workers with more education and those who work in geographic areas with relatively high hiring rates and low job loss rates are more optimistic about the impact of trade. Surprisingly, we find that workers' views of trade are not influenced by job characteristics. In the next section, we summarize previous research on workers' perceptions of trade and its impact on job security. We then describe the data used in our analysis, and present our analytical results.

\section{BACKGROUND}

Job characteristics have played a prominent role in research examining the links between globalization and jobs. Specifically, those jobs deemed to be vulnerable to displacement by trade, 
in one way or another, have been variously referred to as "offshorable," "tradable," or "movable." After the possibility of large scale services offshoring came to the public's attention in the early 2000s, very large estimates of potential job loss from offshoring were generated by adding up jobs in services occupations with characteristics that allow work to be done remotely (Bardhan and Kroll 2003;Blinder and Krueger 2009;Kletzer 2009).

Recently, researchers have directly examined the relationship between globalization and actual job loss (Harrison, McMillan and Null 2007). They examined data from 1977 to 1999 to reconcile the dichotomy between the popular press reports of job losses to offshore affiliates and the economists' view that domestic jobs and offshore employment are complementary. Harrison et al. found that jobs were added in the United States when international investments were in high wage countries and were lost when investments were in low wage countries. This suggests that offshoring for the purposes of cost cutting is associated with job losses at home. Follow-up work argued that wage declines might not show up in sectors that lose employment from import competition because laid off workers tend to move to lower paying industries where they engage in the same occupation for lower pay, while those workers who remain in the industry experience stable, or even rising wages (Ebenstein, Harrison, McMillan and Phillips 2009).

The theoretical link between workers' perceptions and globalization derives from basic economics. This suggests that a worker's assessment of the impact of trade on her job will depend in part on the ability of employers to reduce costs by moving her job abroad, since the demand for labor reflects the price and costs of the product or service being produced. In addition, a worker's rational assessment of the impact of trade on her career prospects will depend on her individual work history and local labor market conditions. The empirical evidence is unclear, however, as to whether the increases in observed perceptions of job insecurity result 
from personal experiences or from more generalized fears about workplace changes picked up from the media or friends (Fullerton and Wallace 2007).

While there are few direct measures of workers' perceptions of the impact of trade on jobs, studies using the General Social Survey (GSS) to examine workers' perceptions of job security show that the percent of workers who think they are likely to lose their jobs in the next twelve months has tracked the national unemployment rate fairly closely over the past three decades, although fears about job security have been rising over time (Aaronson and Sullivan 1998;Anderson and Gascon 2007;Fullerton and Wallace 2007;Schmidt 1999). Workers' perceptions of job security exhibit similar trends using actual involuntary job loss rates obtained from the Displaced Workers Survey (Schmidt 1999).

The link between perceptions and globalization was indirectly examined by Anderson \& Gascon (2007), who found workers' fears about job security increased as "tradability" of jobs by occupation increased. However, when controls for unobserved individual-specific differences (i.e., general individual happiness and change in financial situation) were added, the individualspecific variables played a greater role in predicting workers' perceptions of economic insecurity than the tradability variables did. Similar trends were found when the authors looked at marginal effects using a pseudo panel drawn from the GSS - again, individual-effect variables played a greater role in predicting workers' economic insecurity than tradability variables.

The link between the technological demands of jobs and perceptions of job security was examined by constructing a pseudo-panel using GSS data between 1977 and 1996 (Aaronson and Sullivan 1998). This research found that workers in more computer-intensive industries were less secure about their jobs, the reverse of prior trends; that workers in Census regions and industries 
with higher unemployment rates felt less secure; and that workers at smaller sites were less likely to be concerned about losing their jobs.

How reliable are workers' perceptions of economic activity relative to actual economic outcomes? A recent review of the evidence, which included an analysis of Health and Retirement Survey data, found that subjective job loss expectations have significant predictive power in explaining future job losses, even after controlling for demographic variables, and that higher subjective job loss probabilities are correlated with an increased expectation of future earnings decline. (Stephens 2004). These results suggest that the subjective job loss expectations variable is a meaningful predictor of subsequent job displacement.

The literature on the offshorability of jobs has used indirect measures of job characteristics. Economists have developed a variety of measures based on occupational characteristics (Blinder and Krueger 2009;Kletzer 2009). In one example of this approach, survey respondents were directly asked about the difficulty of having their work performed by someone in a remote location (Blinder and Krueger 2009). The researchers decided how offshorable each job was based on the respondent's job description; they then used professional coders to rank the offshorability of each occupation. Another example identifies a list of U.S. occupations (at the 3-digit level) that are "potentially affected by offshoring." This relies on "offshorability attributes" of occupations, including the use of information and communication technologies, the use of highly codifiable knowledge, and the degree of face-to-face contact (Welsum and Reif 2009).

The most sophisticated attempt to classify jobs according to their vulnerability to trade is the movability index, or "M Index" developed by (Jensen and Kletzer 2006). This measure uses the detailed job descriptions used in the Occupational Information Network $(\mathrm{O} * \mathrm{NET})$ database to 
characterize work in specific occupations. ${ }^{1}$ The $M$ index assigns a value to each 6-digit occupational code based on an examination of the $\mathrm{O}$ *NET job description and researchers' characterization of how movable the occupation is, based on the degree of face-to-face customer contact, use of codifiable information, and appearance of internet enabled work processes. The M Index is based upon eleven job characteristics divided into two categories: information content (e.g., getting, processing, analyzing information; internet enabled) and job process (e.g., face-to-face contact; performing or working directly with the public; routine nature of work in making decisions and solving problems). The $\mathrm{M}$ index is typically negative; the less negative the number, the more movable the occupation.

If we expect the state of the local labor market to play a role in workers' perceptions of vulnerability to job loss, is local unemployment rate an adequate measure? Although the literature makes extensive use of the Local Area Unemployment Statistics, these data have very high standard errors ${ }^{2}$. Even if correctly measured, unemployment rates might not be provide a good measure of local labor market activity. Recent work has documented job loss, job accessions, and unemployment using the Job Openings and Labor Turnover Survey.

(Hall 2005) documented job loss, job finds, and unemployment using the Job Openings and Labor Turnover Survey beginning in Dec 2000, and compared this with data from various surveys conducted over the past 50 years, Hall found the separation rate to be nearly constant while the job-finding rate exhibited high volatility. This suggests that job loss is not the key factor driving fluctuations in unemployment. Recessions involve small increases in the flow of

\footnotetext{
${ }^{1}$ The O*NET, formerly the Dictionary of Occupational Titles (DOT), is the U.S. Bureau of Labor Statistics' primary source for occupational information. See: https://onet.rti.org/

${ }^{2}$ http://www.bls.gov/lau/lastderr.htm
} 
workers out of jobs; unemployment rises almost entirely because jobs become harder to find. This pattern has also been observed in the French labor market (Abowd, Corbel and Kramarz 1999). This research indicates that the state of the local labor market is better represented by the separation and hiring rates than by the local unemployment rates.

\section{Data on TRAde Impact, CAReER PATH, Job Characteristics, AND LOCAL LABOR MARKETS}

This paper draws on new data from the 2008 General Social Survey (GSS), a scientifically valid, national probability sample of non-institutionalized adults administered every two years and made publicly available online. ${ }^{3}$ Core GSS data contain detailed demographic and employment information, including age, sex, household composition, labor market status, education, race, family income, earnings from respondent's employment, hours of work, firm size, job satisfaction, and union status.

In the 2008 GSS, we added a module of cognitively tested questions for full-time workers aged 25 to 55 that asked about workers' career paths, job characteristics, and perceptions of the impact of trade on jobs. We then tied each GSS respondent to their local hiring and separation rates, drawn from the U.S. Census Bureau's Quarterly Workforce Indicators $(\mathrm{QWI})^{4}$, and ranked the tradability of their reported occupations using Jensen and Kletzer's M index. The GSS questions are central to our analysis, so we present them in detail.

The two core GSS questions on workers' perceptions of job security are:

Job Loss: "Thinking about the next 12 months, how likely do you think it is that you will lose your job or be laid off-very likely, fairly likely, not too likely, or not at all likely?"

\footnotetext{
${ }^{3}$ See http://www.norc.org/GSS+Website/

${ }^{4}$ See http://lehd.did.census.gov/led/datatools/qwi-online.html.
} 
Finding another job: "About how easy would it be for you to find a job with another employer with approximately the same income and fringe benefits you now have-very easy, somewhat easy, or not easy at all?"

To this set of questions, we asked a series of additional questions on trade perceptions, career histories and job characteristics.

Worker's perception of the impact of trade on jobs We asked the following question:

"Suppose two friends of yours are talking about trade with other countries. One friend thinks that increased trade has created a lot of jobs in the United States for people with jobs like yours. The other friend thinks that increased trade has taken away a lot of jobs in the United States for people with jobs like yours. Which view is closer to your own?"

The respondent had five options: Created more jobs, taken them away, about the same, not relevant for my job, don't know. If the response was “created more jobs," a follow-up question asked: "On average, do you think the jobs that have been created in the United States for people with jobs like yours are better than your job (i.e., with higher pay and better benefits), worse, or about the same?" variable "trade impact" 6

We also collected information on career paths and current job characteristics:

Career path: "How many years have you worked for your current employer? Thinking about your current employer, how much has your pay increased on your current job since

${ }^{5}$ In the empirical analysis below, these three variables were combined into one variable with seven categories: for job loss: lost better jobs, lost equivalent jobs, lost worse jobs; no change or not relevant; for job creation: created worse jobs, created equivalent jobs, created better jobs. Note that all GSS variables were coded in this dataset to facilitate interpretation of results: higher values indicate "better or improved"; lower values indicate "worse or deterioriated".

${ }^{6}$ In the empirical analysis this measure has seven categories: 1-3 Jobs lost (better, same, worse jobs), 4 No loss, 5-7 Jobs created (better, same, worse). 
you began? When you went to work for your current employer, was your starting pay higher, lower or about the same as what you were earning in your previous (full time) job?"

Job characteristics: "Do you use a computer or computerized equipment at work? How essential is a computer or computerized equipment for your job? How often do you meet face-to-face with customers, clients, patients, or others to whom you provide products or services? How often do you meet face-to-face with co-workers to work on projects, for example solving special problems or improving products or services? ${ }^{7}$ How often do you exchange information with co-workers located outside the United States? ${ }^{8}$,

We then supplemented the GSS data with the M index and QWI variables, as mentioned above. To compare the respondent's job characteristics to the M Index, we mapped the M index to each GSS respondent in our data set based on their reported occupation code. ${ }^{9}$ For each GSS respondent, we used the QWI to quantify hiring and separation rates by gender, NAICS industry, and age in each GSS respondent's standard metropolitan area (SMA) in the fourth quarter 2007. The QWI are derived from universe administrative, linked employer-employee data matched to individual, employment, and employer characteristics files. These combined data create a set of thirty employment and earning measures tabulated by demographic characteristics (sex and eight age categories), geography (county, metropolitan area, and Workforce Investment Area) and

\footnotetext{
${ }^{7}$ Unfortunately this question was not asked correctly by the interviewer, and respondents gave all interactions with coworkers rather than those for special projects. Therefore we did not use this variable.

${ }^{8}$ These frequencies were transformed: 0 (never); 1 (once per year or less); 5 (several time per year); 50 (several times per month); 150 (several times per week); 250 (daily).

${ }^{9}$ The GSS reports 1980 census occupation codes and does not report SOC codes, and we had to convert the GSS occupation codes to SOC codes in order to use Kletzer's M index. Because the SOC is more detailed than the GSS occupation categories, it was necessary in some cases to take weighted averages of multiple tradability scores for one GSS industry. To check sensitivity to this transformation, we created three M indices: an average M index, a "minimum $\mathrm{M}$ index" that uses the lower tradability scores, and a "maximum $\mathrm{M}$ index" that uses the higher tradability scores whenever weights for combining occupations were not available.
} 
industry (4-digit NAICS and SIC Division). A major advantage of these data is that the sample size is very large, permitting highly accurate estimations of labor market flows. To protect confidentiality the estimates are produced using multiple imputation techniques, rather than cell suppression (Abowd, Haltiwanger and Lane 2004). The statistical results below using the QWI data present the ten implicates in our estimates.

In order to compare the QWI hiring and separation rates to the commonly used SMA unemployment rate, we mapped the SMA unemployment rate provided by the Local Area Unemployment Division of the Bureau of Labor Statistics to each GSS respondent. ${ }^{10}$ The BLS merged monthly unemployment data into two quarterly unemployment rates (fourth quarter 2007 and first quarter 2008) and combined the two quarter average unemployment rate for each of the statistical areas represented in the GSS. The data are not seasonally adjusted.

\section{DESCRIPTIVE RESULTS}

We begin our analysis of the data by comparing our data on workers' views on trade, local hiring and separation rates, and job characteristics with commonly used proxies for workers' views on job security, local unemployment rates, and the M Index, respectively. We also describe our other key variables.

Because the variables for trade impact and career paths are available only in the 2008 GSS, we are restricted to one year of analysis. In the 2008 GSS, a maximum of 1456 full time workers age 25 through 62 were eligible to respond to our questions on globalization, and approximately $1250(86 \%)$ responded to most questions. ${ }^{11}$

\footnotetext{
${ }^{10}$ We thank Tom Krolik at the BLS for providing us with the data.

${ }^{11}$ Some cases (185) could not be mapped to the M index, and some respondents did not answer all questions.
} 
Workers' views on trade impact and job security. In this paper we focus on workers' reported views on the impact of trade, because it is newly available data. However, we compare the trade impact results to the analogous job security results commonly used in prior research using GSS data. We find that workers' views on the impact of trade on jobs are slightly correlated with their thinking they can find a new job (0.10) and will not lose their job (0.07), and that the two measures of job security are positively correlated (0.19).

The 2008 GSS was conducted in the first quarter 2008, when the national unemployment rate was 5\%; unemployment rates during the 2008-2009 recession did not begin to increase sharply until May 2008. ${ }^{12}$ In the 2008 GSS approximately one-half (52\%) of workers reported that trade does not affect or is not relevant for "jobs like theirs"; almost one-third (31\%) thought that trade causes loss of jobs, and only one-sixth (17\%) thought that trade creates jobs. As Table 3 shows, and consistent with earlier evidence, industry matters: 50\% of workers in manufacturing think trade causes jobs to be lost, and expect the losses to occur with jobs that are worse than theirs. More surprisingly, because their jobs are not highly tradable, workers in retail and wholesale trade view trade almost as negatively as manufacturing workers. By contrast, twothirds of workers in business and health/legal/education services think that trade has no impact on (or is not relevant for) their jobs. Notably, very few workers (4\% to 7\%) in any industry think trade has created better jobs.

As Table 2 shows, on the brink of a sharp deterioration in the labor market, the overwhelming majority of workers in the GSS were not concerned about losing their jobs, although almost half thought it would not be easy to find a comparable job. Even though $31 \%$ of workers thought that trade caused job loss, only $15 \%$ of workers thought they might lose their

\footnotetext{
${ }^{12}$ http://data.bls.gov/PDQ/servlet/SurveyOutputServlet?data_tool=latest_numbers\&series_id=LNS14000000
} 
jobs over the next year. Interestingly, only $17 \%$ of workers think trade creates jobs and most workers think trade has no impact on jobs like theirs. In sum, this suggests that trade impact and job security variables are largely measuring different phenomena.

We examined the link between workers' perceptions of trade impact and job security and their labor market histories using standard measures of career paths, (see Table 4). We found that more educated workers and those who have experienced wage growth and have higher earnings are more optimistic about the impact of trade, and also more optimistic about not losing their jobs and about finding new jobs. However, long-tenured workers, while less concerned about losing their jobs, are also less optimistic about finding a new job and about the impact of trade compared to workers with shorter tenure.

Overall, in early 2008, workers did not seem especially concerned about the impact of trade or about the prospect of losing their jobs, although they thought that finding a new job would be difficult. We can surmise that the 2008-2009 recession likely reduced their optimism about job loss and confirmed their fears about finding a new job.

Local hiring, separation, and unemployment rates. The relationship between local unemployment rates and hiring and separation rates by gender are graphically presented in Figure $1^{13}$. QWI data for fourth quarter 2007 are used because we assume that workers' information and perceptions about the local labor market are based on the recent past rather than on-going conditions that have not yet been reported.

\footnotetext{
${ }^{13}$ The hiring and separation rates are truncated at .4 - we omitted one outlier which distorted the graph.
} 
Figure 1 shows a high covariance of MSA unemployment rates and MSA hiring and separation rates by gender across MSAs. ${ }^{14}$ In contrast to Hall's (2005) time series findings that lack of new hires rather than loss of jobs is the key factor driving fluctuations in unemployment (i.e., the separation rate is nearly constant while the job-finding rate shows high volatility over time), our 2008 data show that both separation rates and hiring rates move slightly with the unemployment rate across SMAs. However, consistent with Hall's time series findings, the local unemployment rate has a stronger statistical relationship and a much higher simple correlation with the separation rate $(0.48)$ than with the hiring rate $(-0.09)$ across SMAs.

The QWI variables on hiring and separation rates show greater variation than the unemployment across SMAs, and the hiring and separation rates for SMAs with the same unemployment rate can be quite different. Table 1 compares these local labor market measures for San Francisco, Chicago, and New York. Although San Francisco and New York both have unemployment rates of $4.8 \%$, the hiring and separation rates are higher in New York than San Francisco. The net job growth rate (i.e., hiring minus separation rates) is positive for men and negative for women in San Francisco; in New York the net job growth rate is positive for both men and women. Of the three cities Chicago's local unemployment rate is a relatively high $5.7 \%$, with the hiring rate the highest for women (12.6\%) and lowest for men $(8.1 \%)$, yet even in this city the net job growth rate for men is positive. Overall we can see that the QWI variables present a more complex picture of the local labor market than the unemployment rate.

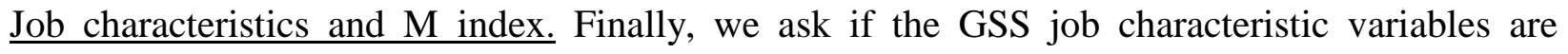
measuring similar tradability characteristics as the M Index. A linear regression of the M index

\footnotetext{
${ }^{14}$ We found a similar relationship of MSA unemployment rates with hiring and separation rates by industry and by age/sex. The MSA unemployment rate was also significantly negatively related to the net change in employment (by sex, industry, and age/sex).
} 
on the three GSS job characteristics shows that "works with international co-workers" is significant, i.e., more international interactions with co-workers goes with more tradable occupations. However, the M index is not significantly related to the GSS measures capturing the use of computers on the job or capturing face-to-face interactions with customers. In addition, the three GSS job characteristics are not significantly correlated. Overall we think that the GSS measures are capturing more complex, and different, aspects of a worker's job than are available from general occupational measures ${ }^{15}$.

\section{ANALYTICAL RESULTS}

We use ordered probit regressions to examine the relationship between workers' perceptions of the impact of trade on jobs and workers' career paths (education, wage trajectory between jobs and on current job, years with current employer; current earnings); job characteristics (computer use, face-to-face contact with customers, contact with foreign coworker, $M$ index), and SMA labor market conditions (hiring and separation rates, ${ }^{16}$ unemployment rate). We also include a number of controls: demographic (age, sex, marital status), industry (eight categories) ${ }^{17}$, and firm characteristics (size, union, self-employed). To control for individual specific effects, we use two variables to indicate unobserved personality and attitude attributes such as optimistic or fearful: "Taken all together, how would you say things are these days--would you say that you are very happy, pretty happy, or not too happy?"

\footnotetext{
${ }^{15}$ These results hold when comparing the GSS job characteristics with the minimum and maximum estimates for the $\mathrm{M}$ index. Results available upon request.

${ }^{16}$ Hiring and separation rates are by gender for the SMA. Results are robust using these QWI variables by industry.

17 Industry dummies are created from the GSS industry variable, which uses the ten Census industry groups (http://unionstats.gsu.edu/Ind3 80.htm). We combined the three manufacturing categories into one category to make an industry dummy variable with eight groups 1 Agriculture, Mining, Construction; 4 Manufacturing; 5 Transportation, Communications, Public Utilities; 6 Wholesale Trade; 7 Retail Trade; 8 Finance, Insurance, and Real Estate, Business Services, Personal Services; 9 Entertainment and Recreation Services, Professional and Related Services; and 10Public Administration the excluded benchmark.
} 
and "During the last few years, has your financial situation been getting better, worse, or has it stayed the same?". The results are reported in Table 5.

Our main finding is that workers' perceptions of the impact of trade on jobs are significantly related to local labor market conditions and education (see Table 5, column 1). Workers feel more positive about the impact of trade when the SMA hiring rate increases and the separation rate decreases; the local unemployment rate is not significant. Workers with more education are more likely to view trade positively. Surprisingly, given the literature on the possible contributors to negative views on trade, education is the only significant career path variable and no job characteristics are significant, given local labor market conditions.

Adding industry dummies as controls has little impact on results (Table 5, column 2), only construction/agriculture/mining is significantly different from public administration (the benchmark), and workers in this group of industries view trade more negatively. Controls for demographic and firm characteristics also have little impact on the results (Table 5, column 3). The only significant control is if the worker is married, with married respondents having a more positive perception of the impact of trade on jobs. The controls for individual specific effects are not significant; with these controls, being married is insignificant (Table 5, column 4). Similarly, including the M Index has little impact on results, and the M Index is not significant (Table 5, column 5). ${ }^{18}$ In sum, workers' perceptions about the impact of trade on jobs across SMAs reflect their education and conditions in the local labor market, and not their own experiences in the labor market. Job characteristics, and the potential to move certain occupations abroad, do not seem to influence workers' views on trade.

\footnotetext{
${ }^{18}$ To check robustness of the QWI variables, we ran the regressions without the SMA unemployment rate, and the QWI coefficients were slightly larger. We also dropped the earnings variable to check its reliability, because missing observations had been filled in. Dropping earnings did not alter the regression results
} 
We also examine the same ordered probit regressions for the two job security variables, and report the results along with the earlier results for trade impact in Table $6 .{ }^{19}$ In contrast to the results for trade impact, workers' career paths are significantly related to their perceptions of job security. However, job characteristics are still not significant.

A worker's ability to find a comparable job with another employer is likely to be key, given the turbulence in the US job market, where large numbers of jobs are created and destroyed every quarter, is (Brown, Haltiwanger and Lane 2006). We find that a worker's perception of how easy it would be to find a new job is significantly related to the worker's career path. The perception that it would be easy to find a new job goes up with current earnings, and down with both tenure on current job and with having improved earnings upon taking the current job. In other words, workers who have worked for their employers for some time or who were able to improve their earnings when they took their current job fear that they will not face a receptive job market if they have to find a new job.

Workers' general concerns about the national economy and economic policy are often driven by their fear of losing their jobs. We find workers' fear of losing their job to be related to their career paths, as they are to workers' perceptions of how easy it is to find a job. Workers are less likely to think they will lose their jobs over the next year if they are doing well on their current job-if they have long tenure with current employer, have experienced pay raises on

\footnotetext{
${ }^{19}$ Regressions analogous to the one reported in column 4 of Table 8, with M index excluded in order not to drop the 166 cases without $\mathrm{M}$ index, are reported in Table 7. Controls are not reported. Workers' perceptions about finding a new job do vary across industries, and their optimism about finding a new job declines with worker age and with firm size and improves if a computer is not essential for their jobs. In contrast, workers' perceptions about job loss do not demonstrate significant variation across industries or firm and individual characteristics. In our robustness checks on job security regressions, the M Index is significantly negatively related to Find New Job (finding new job easier if job is less movable). The M Index is not significantly related to Job Lose Not Likely.
} 
their current job, and have higher current earnings. Interestingly, higher education is correlated with a worker thinking there is an increased likelihood of losing her job.

Labor market conditions are consistently important. ${ }^{20}$ Workers' perception of the ease of finding a new job is significantly related to the local hiring rate, as expected. The local unemployment rate, rather than the highly correlated separation rate, is significantly related to workers' perceptions about job loss; workers in areas with relatively high unemployment rates are more likely to fear losing their jobs. These results suggest that perceptions of trade are more significantly related to local labor market conditions than workers' perceptions of job security.

Although individual specific effects were not significant in the regressions on impact of trade, the variable for general happiness was significant in both job security regressions, as earlier research has found. However the other individual-specific control for improved financial situation was not significant, although it was significant in previous research. Most likely this reflects the inclusion of the career path variables, which provide an objective measure of the worker's recent earnings trajectory.

It is startling, given the abundant literature on tradability and technology, to see an almost complete lack of relationship between job characteristics and workers' perceptions about the impact of trade and job security. The evidence presented in Tables 5 and 6 suggests that there is no significant relationship between the workers' perceptions of the impact of trade, or of job security, and their job characteristics with one exception: face-to-face interactions with customers is correlated with less concern about job loss, as predicted by the literature.

Overall these results indicate that workers' perceptions of the impact of trade mainly reflect their local labor market conditions and their education. Career paths, as well as local labor

\footnotetext{
${ }^{20}$ Hiring rate is by gender for the MSA, and results are robust using the hiring rate by industry.
} 
market conditions, influence their views about finding or losing jobs. Job characteristics do not seem to be an important influence on workers' perceptions about trade or job security. These results generally support the proposition that workers' negative views about the impact of trade reflect local labor market conditions rather than the job characteristics that make their jobs tradable or their own experiences in the labor market. For policy purposes, this result suggests any public backlash against trade is more likely to be related to local labor market conditions, and suggests that research that demonstrates how a variety of factors, including trade and aggregate demand, impact local labor markets is critical in developing appropriate policies ${ }^{21}$.

\section{CONCLUDING COMMENTS}

We have based our analysis on new, detailed information about the relationship between workers' views of the impact of trade and their own job characteristics, career paths, and local labor market conditions. Our main conclusion is that workers' perceptions closely track the economic realities imparted by their local labor markets and levels of education. Workers do not appear to think that the movability of their jobs, as defined by economists, affects how trade will impact jobs like theirs or their likelihood of losing a job or finding another job. Workers' career paths and their individual specific measures of happiness are related to their views about job security, but not about the impact of trade.

Despite a substantial recent literature arguing that workers with tradable jobs worry about their jobs being vulnerable to overseas competition, our analysis, using new data with direct measures of such characteristics, finds no evidence to support this view. Views of the impact of trade are impervious to the tradability of a workers' job as measured by requirements for face-to-

\footnotetext{
${ }^{21}$ We note that these results are limited by use of only 2008 data, and the analysis needs to be repeated when multiyear data are available to control for year and fixed effects.
} 
face contact with customers and the technological content of the job. The main factors that shape views of trade are education and local labor market conditions. Policies that focus on improving local labor market conditions should have a positive impact on how workers view trade. 


\section{REFERENCES}

Aaronson, Daniel and Daniel Sullivan. 1998. "The Decline in Job Security in the 1990s: Displacement, Anxiety, and Their effect on Wage Growth." Federal Reserve Bank of Chicago Economic Perspectives 22 (1): 17-43.

Abowd, John, Patrick Corbel and Francis Kramarz. 1999. "The Entry and Exit of Workers and the Growth of Employment: An Analysis of French Establishments." Review of Economics and Statistics 81 (2): 170-187.

Abowd, John, John Haltiwanger and Julia Lane. 2004. "Integrated Longitudinal Employer-Employee Data for the United States." American Economic Review 94 (2): 224-229.

Anderson, Richard and Charles Gascon. 2007. "The Perils of Globalization: Offshoring and Economic Insecurity of the American Worker." St Louis: St Louis Fedeal Reserve.

Bardhan, Ashok and Cynthia Kroll. 2003. "The New Wave of Outsourcing.". Fisher Center for Real Estate \& Urban Economics.

Blinder, Alan and Alan Krueger. 2009. "Alternative Measures of Offshorability: A Survey Approach." In National Bureau of Economic Research.

Brown, Clair, John Haltiwanger and Julia Lane. 2006. Economic Turbulence. Chicago: University of Chicago Press.

Ebenstein, Avraham, Ann Harrison, Margaret McMillan and Shannon Phillips. 2009. "“Estimating the Impact of Trade and Offshoring on American Workers Using the Current Population Surveys." In National Bureau of Economic Research Working Paper.

Eichengreen, Barry. 2010. "The Great Recession and the Great Depression: Reflections and Lessons." In Central Bank of Chile Working Paper Series.

Fullerton, Andrew S. and Michael Wallace. 2007. "Traversing the flexible turn: US workers' perceptions of job security, 1977-2002 " Social Science Research 36 (1): 201-221.

Gomory, Ralph E. and William J. Baumol. 2001. Global Trade and Conflicting National Interests. Cambridge, MA: MIT Press.

Hall, Robert. 2005. "Job Loss, Job Finding and Unemployment in the U.S. Economy over the Past 50 Years " In National Bureau of Economic Research Working Paper.

Harrison, Ann, Margaret McMillan and Clair Null. 2007. "U.S. Multinational Activity Abroad and U.S. Jobs: Substitutes or Complements?" Industrial Relations 47: 347-365.

Jensen, J. Bradford and Lori Kletzer. 2006. "Tradable Services: Understanding the Scope and Impact of Services Offshoring." In Brookings Trade Forum 2005, Offshoring White-Collar Work, edited by Susan Collins and Lael Brainard.

Kletzer, Lori. 2009. "Understanding the Domestic Labor Market Impact of Offshore Services Outsourcing: Measurement Issues." In Measurement Issues Arising from the Growth of Globalization, edited by W.E. Upjohn Institute for Employment Research and the National Academy of Public Administration.

O'Rourke, Kevin H. 2003. "Heckscher-Ohlin Theory and Individual Attitudes Towards Globalization." C.E.P.R. Discussion Papers.

Rodrik, Dani. 1997. Has Globalization Gone Too Far? . Washington, DC: Petersen Institute of for International Economics. .

Scheve, Kenneth F. and Matthew J. Slaughter. 2001. Globalization and the perceptions of American Workers. Washington, DC: Institute For International Economics.

Schmidt, Stefanie. 1999. "Long-Run Trends in Workers' Beliefs about Their Own Job Security: Evidence from the General Social Survey." Journal of Labor Economics 17 (4): 127-141.

Stephens, Melvin. 2004. "Job Loss Expectations, Realizations, and Household Consumption Behavior." Review of Economics and Statistics 86 (1): 253-269. 
Welsum, Desireé van and Xavier Reif. 2009. "We Can Work It Out: The Globalization of ICT-Enabled Services." National Bureau of Economic Research, Inc. 
FIGURE1: THE RELATIONSHIP BETWEEN THE LOCAL UNEMPLOYMENT RATES, HIRING, AND SEPARATION RATES
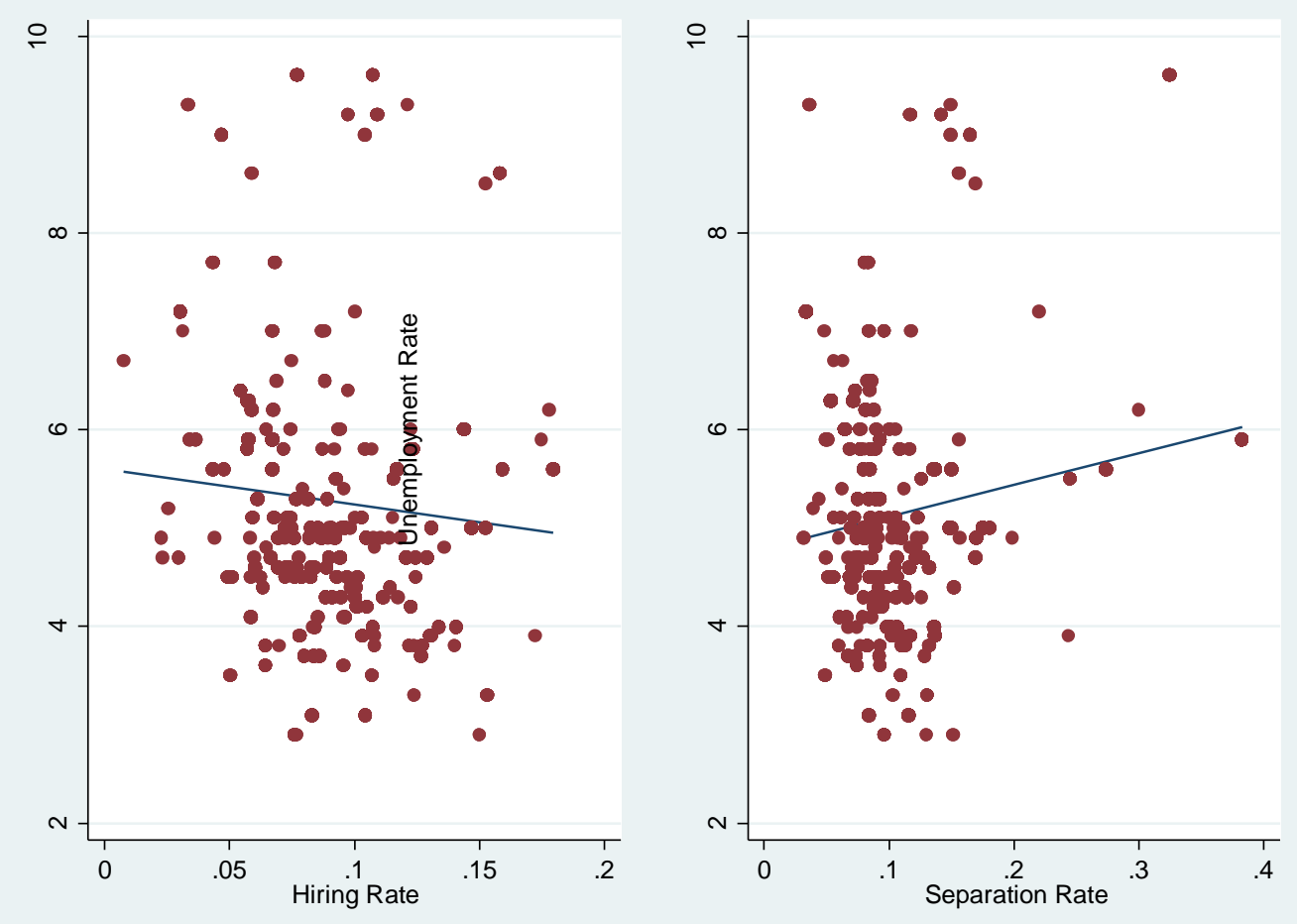


\begin{tabular}{|c|c|c|c|}
\hline & San Francisco & Chicago & New York \\
\hline Hiring Rate (M) & $8.9 \%$ & $8.1 \%$ & $9.5 \%$ \\
\hline Hiring Rate $(\mathbf{F})$ & $9.6 \%$ & $12.6 \%$ & $10.0 \%$ \\
\hline Separation Rate (M) & $8.1 \%$ & $7.6 \%$ & $8.6 \%$ \\
\hline Separation Rate (F) & $8.2 \%$ & $8.8 \%$ & $11.5 \%$ \\
\hline Unemployment Rate & $4.8 \%$ & $5.7 \%$ & $4.8 \%$ \\
\hline \multicolumn{4}{|c|}{ Source: Authors' calculations } \\
\hline
\end{tabular}




\begin{tabular}{|l|l|l|l|}
\hline \multicolumn{5}{|c|}{ Table 2: Views on Job Security } \\
\hline Likely to lose job? & Proportion & Ease of Finding Similar Job & Proportion \\
\hline Very Likely & 4.53 & Not easy & 47.32 \\
\hline Fairly Likely & 10.29 & Somewhat easy & 31.62 \\
\hline Not Too Likely & 28.39 & Very easy & 21.06 \\
\hline Not Likely & 56.79 & & \\
\hline Source: Authors' calculations & \\
\hline
\end{tabular}




\begin{tabular}{|c|c|c|c|c|c|}
\hline \multicolumn{6}{|c|}{$\begin{array}{l}\text { Table 3: Views on Trade Impact } \\
\text { By workers' industry sector }\end{array}$} \\
\hline & Manufacturing & Business Service & $\begin{array}{l}\text { Health/Education/ } \\
\text { Legal Services }\end{array}$ & $\begin{array}{l}\text { Retail/ } \\
\text { Wholesale Trade }\end{array}$ & All Industries \\
\hline \multicolumn{6}{|c|}{ Jobs Lost } \\
\hline Better jobs & $9 \%$ & $5 \%$ & $3 \%$ & $5 \%$ & $5 \%$ \\
\hline $\begin{array}{l}\text { Equivalent } \\
\text { jobs }\end{array}$ & $13 \%$ & $5 \%$ & $3 \%$ & $8 \%$ & $6 \%$ \\
\hline Worse jobs & $28 \%$ & $16 \%$ & $15 \%$ & $23 \%$ & $20 \%$ \\
\hline \multicolumn{6}{|c|}{ No Loss/No Response } \\
\hline & $35 \%$ & $63 \%$ & $66 \%$ & $46 \%$ & $52 \%$ \\
\hline \multicolumn{6}{|c|}{ Jobs Created } \\
\hline Worse jobs & $1 \%$ & $6 \%$ & $4 \%$ & $4 \%$ & $4 \%$ \\
\hline $\begin{array}{l}\text { Equivalent } \\
\text { jobs }\end{array}$ & $7 \%$ & $1 \%$ & $5 \%$ & $11 \%$ & $8 \%$ \\
\hline Better jobs & $7 \%$ & $5 \%$ & $5 \%$ & $4 \%$ & $5 \%$ \\
\hline \multicolumn{6}{|c|}{ Source: Authors' calculations } \\
\hline
\end{tabular}




\begin{tabular}{|l|c|c|c|}
\hline \multicolumn{5}{|c|}{ Table 4: Views on job security and trade impact by career path } \\
\hline & More Trade Better & Job Loss Not Likely & Easy to Find New Job \\
\hline Degree & $.126^{*}$ & .02 & $.11^{*}$ \\
& $(.02)$ & $(.04)$ & $(.03)$ \\
\hline Tenure at current employer & -.002 & $.002^{*}$ & $-.02^{*}$ \\
& $(.004)$ & $(.004)$ & $(.005)$ \\
\hline Earnings & $.003^{*}$ & $.005^{*}$ & $.004^{*}$ \\
& $(.001)$ & $(.001)$ & $(.001)$ \\
\hline Wage growth & $.122^{*}$ & $.289^{*}$ & $.137^{*}$ \\
& $(.05)$ & $.056)$ & $.044)$ \\
\hline Standard errors in parentheses; corrected for clustered nature of the sample; ${ }^{*}$ significant at 1\% level \\
\hline
\end{tabular}




\begin{tabular}{|c|c|c|c|c|c|}
\hline \multicolumn{6}{|c|}{ Table 5: More Trade Better } \\
\hline & 1 & 2 & 3 & 4 & 5 \\
\hline \multicolumn{6}{|c|}{ Local Labor Market Characteristics } \\
\hline \multirow[t]{2}{*}{ Local Hiring Rate } & $5.53 * * *$ & $5.05 * * *$ & $5.06^{* * *}$ & $4.81 * * *$ & $3.51^{* *}$ \\
\hline & $(1.54)$ & $(1.46)$ & $(1.48)$ & $(1.47)$ & $(1.51)$ \\
\hline \multirow{2}{*}{ Local Separation Rate } & $-1.17 * * *$ & $-1.17 * * *$ & $-1.19 * * *$ & $-1.20 * * *$ & $-1.18 * *$ \\
\hline & $(.37)$ & $(.39)$ & $(.42)$ & $(.41)$ & $(.50)$ \\
\hline \multirow[t]{2}{*}{ Local Unemployment Rate } & -.02 & -.02 & -.02 & -.02 & -.02 \\
\hline & $(.03)$ & $(.03)$ & $(.03)$ & $(.03)$ & $(.03)$ \\
\hline \multicolumn{6}{|c|}{ Job Characteristics } \\
\hline \multirow{2}{*}{ M index } & & & & & .04 \\
\hline & & & & & $(.06)$ \\
\hline \multirow[t]{2}{*}{ Computer Use On Job } & -.05 & -.03 & -.02 & -.02 & -.03 \\
\hline & $(.04)$ & $(.04)$ & $(.05)$ & $(.05)$ & $(.05)$ \\
\hline \multirow[t]{2}{*}{ Foreign Coworker Interactions } & .09 & .10 & .10 & .10 & .13 \\
\hline & $(.10)$ & $(.10)$ & $(.10)$ & $(.09)$ & $(.10)$ \\
\hline \multirow[t]{2}{*}{ Customer Face-to-Face Contacts } & .01 & -.01 & .00 & .00 & .05 \\
\hline & $(.04)$ & $(.04)$ & $(.04)$ & $(.04)$ & $(.05)$ \\
\hline \multicolumn{6}{|c|}{ Worker Career Paths } \\
\hline \multirow[t]{2}{*}{ Higher Wage With Job Change } & .05 & .05 & .05 & .04 & .04 \\
\hline & $(.05)$ & $(.05)$ & $(.05)$ & $(.05)$ & $(.05)$ \\
\hline \multirow[t]{2}{*}{ Degree } & $.10 * * *$ & $.09 * * *$ & $.09 * * *$ & $.09 * * *$ & $.10 * * *$ \\
\hline & $(.03)$ & $(.03)$ & $(.03)$ & $(.03)$ & $(.04)$ \\
\hline \multirow[t]{2}{*}{ Tenure Current Employer } & -.03 & -.03 & -.03 & -.03 & -.05 \\
\hline & $(.04)$ & $(.04)$ & $(.05)$ & $(.05)$ & $(.05)$ \\
\hline \multirow[t]{2}{*}{ Current Earnings } & .15 & .14 & .04 & .00 & -.03 \\
\hline & $(.15)$ & $(.15)$ & $(.14)$ & $(.14)$ & $(.17)$ \\
\hline \multirow[t]{2}{*}{ Wage Increases On Current Job } & .07 & .07 & .06 & .03 & .03 \\
\hline & $(.05)$ & $(.05)$ & $(.05)$ & $(.05)$ & $(.05)$ \\
\hline \multicolumn{6}{|c|}{ Worker Characteristics } \\
\hline \multirow[t]{2}{*}{ Age } & & & -.03 & -.02 & -.03 \\
\hline & & & $(.04)$ & $(.04)$ & $(.04)$ \\
\hline \multirow[t]{2}{*}{ Sex } & & & .08 & .08 & .12 \\
\hline & & & $(.09)$ & $(.10)$ & $(.11)$ \\
\hline \multirow[t]{2}{*}{ Married Couple } & & & $.14 * *$ & .12 & $.17 * *$ \\
\hline & & & $(.07)$ & $(.08)$ & $(.08)$ \\
\hline \multirow[t]{2}{*}{ Self Employed } & & & .07 & .08 & .18 \\
\hline & & & $(.14)$ & $(.14)$ & $(.12)$ \\
\hline \multirow[t]{2}{*}{ Union } & & & -.06 & -.05 & -.09 \\
\hline & & & $(.10)$ & $(.10)$ & $(.11)$ \\
\hline Firm Size & & & .02 & .02 & .04 \\
\hline & & & $(.03)$ & $(.03)$ & $(.04)$ \\
\hline Happy & & & & .08 & .08 \\
\hline & & & & $(.06)$ & $(.07)$ \\
\hline Financial Situation Improving & & & & .07 & .07 \\
\hline Industry Controls & No & Yes & Yes & Yes & Yes \\
\hline Observations & 1222 & 1222 & 1214 & 1208 & 1042 \\
\hline F statistic & 7.27 & 6.10 & 5.14 & 5.25 & 3.97 \\
\hline
\end{tabular}




\begin{tabular}{|c|c|c|c|}
\hline \multicolumn{4}{|c|}{ Table 6: Views on Trade Impact and Job Security } \\
\hline & $\begin{array}{c}\text { More Trade } \\
\text { Better }\end{array}$ & Job Loss Not Likely & $\begin{array}{c}\text { Easy to Find New } \\
\text { Job }\end{array}$ \\
\hline \multicolumn{4}{|l|}{ SMA labor market conditions } \\
\hline \multirow[t]{2}{*}{ Local Hiring Rate } & $4.81 * * *$ & 1.32 & $3.88 * *$ \\
\hline & $(1.47)$ & $(1.58)$ & $(1.85)$ \\
\hline \multirow[t]{2}{*}{ Local Separation Rate } & $-1.20 * * *$ & .37 & -.36 \\
\hline & $(.41)$ & $(.54)$ & $(.48)$ \\
\hline \multirow[t]{2}{*}{ Local Unemployment Rate } & -.02 & $-.08 * *$ & -.05 \\
\hline & $(.03)$ & $(.04)$ & $(.04)$ \\
\hline \multicolumn{4}{|l|}{ Job Characteristics } \\
\hline \multirow[t]{2}{*}{ Computer Use On Job } & -.02 & .07 & -.06 \\
\hline & $(.05)$ & $(.04)$ & $(.04)$ \\
\hline \multirow[t]{2}{*}{ Foreign Coworker Interactions } & .10 & .01 & .08 \\
\hline & $(.09)$ & $(.07)$ & $(.07)$ \\
\hline \multirow[t]{2}{*}{ Customers Face-to-Face Contacts } & .00 & $.06 *$ & .04 \\
\hline & $(.04)$ & $(.04)$ & $(.04)$ \\
\hline \multicolumn{4}{|l|}{ Career Path } \\
\hline \multirow[t]{2}{*}{ Higher Wage With Job Change } & .04 & -.04 & $-.10 * *$ \\
\hline & $(.05)$ & $(.05)$ & $(.05)$ \\
\hline \multirow[t]{2}{*}{ Degree } & $.09 * * *$ & $-.13 * * *$ & .04 \\
\hline & $(.04)$ & $(.05)$ & $(.04)$ \\
\hline \multirow[t]{2}{*}{ Tenure Current Employer } & -.03 & $.15 * * *$ & $-.22 * * *$ \\
\hline & $(.05)$ & $(.05)$ & $(.06)$ \\
\hline \multirow[t]{2}{*}{ Current Earnings } & .00 & $.31 *$ & $.62 * * *$ \\
\hline & $(.14)$ & $(.18)$ & $(.17)$ \\
\hline \multirow[t]{2}{*}{ Wage Increases On Current Job } & .03 & $.22 * * *$ & .07 \\
\hline & $(.05)$ & $(.06)$ & $(.05)$ \\
\hline
\end{tabular}

